\title{
Tafsir Ayat-Ayat Teologis dalam al-Muharrar al-Wajiz: Studi Kritis Atas Tuduhan I'tizal terhadap Ibnu Athiyyah
}

\author{
Subi Nur Isnaini \\ Universitas Islam Negeri Sunan Kalijaga Yogyakarta \\ Email: subinurisna@gmail.com
}

Naskah diterima: 25 November 2020, direvisi: 11 Juli 2021, disetujui: 15 Juli 2021

\begin{abstract}
This paper discusses the Ibn Athiyyah positions towards the concept of Muktazilah theology in his exegesis al-Muharrar al-Wajiz. Although Ibn Athiyyah is an interpreter who has Asy'ariyah school of thought, some scholars such as Ibn Taimiyyah, Ahmad bin Hajar alHaitami and Ibn 'Arafah have stated that Ibn Athiyyah interpretation has included the concept of Muktazilah theology. More over, al-Haitami also quoted Ibn 'Arafah's comment that the interpretation of Ibn Athiyyah was more worrying for beginner students than alKasysyaf, because al-Zamakhsyari, the author of al-Kasysyaf, was already known as a Mu'tazili, different with Ibn Athiyyah. This research is a type of qualitative research with a library research approach. By using a descriptive analysis, this paper explores Ibn Athiyyah's interpretation of the verses which are the evidence for the concept of Muktazilah theology or what is often referred to as al-Ushul al-Khamsah. The results of this study shows that the accusation of i'tizal aimed to Ibn Athiyyah is not true, because his interpretation of theological verses shows that Ibn Athiyyah always approves and justifies the Ash'ariyyah opinions. More over, on several occasions Ibn Athiyyah has refuted the opinions and arguments that used Muktazilah to affirm their theological concept.
\end{abstract}

Keywords: Ibn Athiyyah, al-Muharrar al-Wajiz, Muktazilah, Theology, I'tizal

\begin{abstract}
Abstrak
Tulisan ini membahas tentang sikap Ibnu Athiyyah terhadap konsep teologi Muktazilah dalam tafsirnya al-Muharrar al-Wajiz. Meskipun Ibn Athiyyah merupakan mufassir yang bermadzhab Asy'ariyah, namun beberapa ulama seperti Ibnu Taimiyyah (w. 728 H), Ahmad bin Hajar al-Haitami (w. $973 \mathrm{H}$ ) dan Ibnu 'Arafah (w. $803 \mathrm{H}$ ) melontarkan pernyataan bahwa dalam tafsir Ibnu Athiyyah terdapat pemahaman Muktazilah. Bahkan, al-Haitami juga menukil komentar Ibnu 'Arafah bahwa tafsir Ibn Athiyyah lebih mengkhawatirkan bagi pelajar pemula daripada al-Kasysyaf, karena al-Zamakhsyari penulis al-Kasysyaf sudah dikenal sebagai seorang yang bermadzhab Muktazilah, berbeda dengan Ibn Athiyyah. Penelitian ini merupakan jenis penelitian kualitatif dengan pendekatan studi pustaka (library research). Dengan menggunakan metode deskriptif analisis, tulisan ini mengeksplorasi penafsiran Ibnu Athiyyah terhadap ayat-ayat yang menjadi dalil atas konsep teologi Muktazilah atau yang sering disebut dengan al-Ushul al-Khamsah. Hasil penelitian ini menunjukkan bahwa tuduhan i'tizal yang ditujukan pada Ibnu Athiyyah tidaklah benar, karena dalam penjelasan tafsirnya atas ayat-ayat teologis didapati bahwa Ibnu Athiyyah selalu menguatkan dan membenarkan pendapat Asy'ariyyah. Bahkan, dalam beberapa kesempatan Ibnu Athiyyah menyanggah pendapat-pendapat serta dalil-dalil yang digunakan Muktazilah untuk menguatkan konsep teologis mereka.
\end{abstract}

Kata Kunci: Ibn Athiyyah, al-Muharrar al-Wajiz, Muktazilah, Teologi, I'tizal 


\section{A. Pendahuluan}

Upaya memahami al-Qur'an melalui kajian dan penafsiran tidak pernah mengenal kata final. Lafadz-lafadz al-Qur'an yang mengandung berbagai kemungkinan makna (wujuh al-ma'ani) menjadikannya dapat terus digali dan ditafsirkan sesuai metode dan kecenderungan penafsir. Di sisi lain kondisi sosio-kultural dan politik yang melingkupi kehidupan penafsir serta spesialisasi keilmuan yang dimiliki, turut mempengaruhi perbedaan sudut pandang dalam memahami al-Qur'an. Berbagai corak dan ragam tafsir mulai muncul terutama pada akhir Dinasti Umayyah dan awal Daulah Abbasiyah. Berbeda dengan penafsiran masa periode klasik, terutama pada masa sahabat yang tidak bersifat sektarian dan tidak membela kepentingan madzhab tertentu, pada masa ini mulai muncul penafsiran yang mencerminkan bias-bias ideologi kelompok tertentu hingga memunculkan berbagai corak penafsiran dengan menggunakan pemikiran atau ijtihad berfikir yang berkembang saat itu.

Penafsiran dengan menggunakan ijtihad berfikir tersebut kemudian dikenal dengan tafsir bi al-ra'y yang validitasnya masih diperdebatkan oleh ulama. Husein al-Dzahabi dalam al-Tafsir wa al-Mufassirun menyatakan bahwa perbedaan pendapat antar ulama tentang validitas tafsir bi al-ra'y hanyalah perselisihan yang bersifat lafdzi bukan haqiqi, karena ijtihad berfikir menurutnya terbagi menjadi dua: ijtihad yang sesuai dengan kaidah bahasa Arab, al-Qur'an dan Sunnah serta memenuhi syarat-syarat tafsir yang baik, maka ijtihad dalam tafsir yang seperti ini diperbolehkan dan dapat diterima. Sedangkan ijtihad penafsiran yang tidak sesuai dengan kaidah bahasa Arab, tidak sesuai dengan al-Qur'an dan hadis, tidak memenuhi syarat-syarat penafsiran yang baik maka ijtihad tafsir seperti ini tidak diperbolehkan dan tidak dapat diterima. Atas dasar inilah, al-Dzahabi mengklasifikasikan tafsir bi al-ra'y ke dalam dua kelompok, yaitu al-tafsir bi al-ra'y al-jaiz dan al-tafsir bi alra'y al-madzmum (al-Dzahabi, 2000).

Tafsir bi al-ra'y memiliki baragam corak dan kecenderungan sesuai dengan spesialisasi disiplin keilmuan yang dikuasai masing-masing mufasir. Para ulama fikih memahami al-Qur'an dari sudut pandang hukum fikih dan menghasilkan karya tafsir yang banyak mengulas hukum fikih yang berkaitan dengan ayat tertentu, seperti al-Jashshash (w. 370 H) dalam Ahkam al-Qur'an, Kiya al-Harasi (w. 504 H) dalam Ahkam al-Qur'an, alQurthubi (w. 672 H) dalam al-Jami' li Ahkam al-Qur'an, dan lainnya. Kaum sufi memahami dan menafsirkan al-Qur'an dari sudut pandang pemikiran dan perjalanan sufistiknya, seperti al-Tusturi (w. 283 H) dalam Tafsir al-Qur'an al-‘Adzim, Ibnu Arabi (w. 638 H) dalam alFutuhat al-Makkiyyah, Ibnu Ajibah (w. 1224 H) dalam al-Bahr al-Madid, dan lainnya. Para 
pakar teologi menafsirkan al-Qur'an dari sudut pandang pemahaman teologis seperti alZamakhsyari (w. 538 H) dalam al-Kasysyaf, Fakhruddin al-Razi (w. 606 H) dalam Mafatih al-Ghaib, dan lainnya. Selain itu, muncul juga corak penafsiran adabi ijtima'i seperti yang dilakukan oleh Muhammad Abduh (w. 1323 H) dan muridnya Muhammad Rasyid Rida (w. 1935 M) dalam Tafsir al-Manar dan corak tafsir 'ilmi seperti yang terlihat dalam Tafsir alJawahir karya Thanthawi Jauhari (w. 1940 M).

Selain corak tafsir yang disebutkan sebelumnya, tafsir bercorak lughawi yang kental dengan analisis bahasa dan qira'at tidak dapat dinafikan bagi perkembangan kajian tafsir dalam khazanah keilmuan Islam. Di antara karya tafsir yang menggunakan pendekatan bahasa dan kerap menyinggung tema-tema teologis secara detail disertai dengan diskusi bagi pendapat antara madzhab dalam akidah adalah Tafsir al-Muharrar al-Wajiz karya Ibnu Athiyyah. Sebagai seorang mufasir yang berakidah Sunni, Ibnu Athiyyah (w. 542 H) menjelaskan makna ayat-ayat teologis sesuai dengan pemahaman dan pemikiran akidah Sunni. Namun beberapa kalangan menyebutkan bahwa Ibnu Athiyyah telah menyusupkan prinsip-prinsip akidah Muktazilah dalam tafsirannya. Karena itu, topik ini menarik untuk dikaji agar didapatkan penjelasan yang sebenarnya terkait benar tidaknya tuduhan tersebut.

Berdasarkan penelusuran penulis, penelitian-penelitian terhadap pemikiran tafsir Ibnu Athiyyah yang telah dilakukan sebelumnya, belum ada yang membahas secara khusus tentang tuduhan i'tizal (kecenderungan mendukung atau mengikuti pendapat Muktazilah) terhadap Ibnu Athiyyah. Beberapa penelitian sebelumnya tentang Ibnu Athiyyah di antaranya penelitian yang berjudul Rasionalitas Penafsiran Ibnu Athiyyah oleh Abdullah Karim (Karim, 2013). Dalam tulisannya ini, Abdullah membahas rasionalitas penafsiran Ibnu Athiyyah dalam al-Muharrar al-Wajiz dan memformulasikannya menjadi tiga hal: penalaran logis, analisis linguistik dan analisis ilmu-ilmu al-Qur'an. Penelitian lain dilakukan oleh Rochmad dengan judul Ibnu Athiyyah wa at-Tarjih fi al-Muharrar al-Wajiz yang menjelaskan metode tarjih yang dipakai Ibnu Athiyyah dalam tafsirnya (Rochmad, 2017). Penelitian tentang ayat-ayat teologis juga belum banyak dilakukan. Penulis mendapatkan penelitian yang dilakukan oleh Zakiyyah dan Ermita dengan judul Aspek Paham Muktazilah dalam Tafsir al-Kasysyaf tentang Ayat-ayat Teologi: Studi Pemikiran alZamakhsyary (Zakiyah, 2013). Penelitian ini menekankan pembahasan pada ayat-ayat teologi Muktazilah dalam tafsir al-Kasysyaf. Dari penelusuran ini diketahui bahwa penelitian tentang tuduhan i'tizal terhadap Ibnu Athiyyah dalam tafsir al-Muharrar al-Wajiz belum dilakukan. Karena itu, melalui artikel ini penulis ingin menguak penafsiran Ibnu Athiyyah terhadap ayat-ayat teologis yang menjadi dalil dari prinsip-prinsip akidah 
Muktazilah dalam kitab tafsirnya al-Muharrar al-Wajiz dengan menggunakan metode deskriptif analitis. Penelitian ini bertujuan untuk mendapatkan penjelasan ilmiah dan pemahaman yang lebih jelas terkait tuduhan i'tizal tersebut.

\section{B. Metode Penelitian/Metode Kajian}

Penelitian ini merupakan jenis penelitian kualitatif dengan pendekatan studi pustaka (library research). Objek utama dalam penelitian ini adalah tafsir Al-Muharrar al-Wajiz fi Tafsir al-Qur'an al-Aziz karya Ibnu Athiyyah sebagai sumber primer dan sejumlah referensi terkait dengan kajian ayat-ayat teologis dalam al-Qur'an, tafsir Ibnu Athiyyah, dan bukubuku biografi (tabaqat dan fahrasah)sebagai sumber sekunder. Dalam prosesnya, penelitian ini dilakukan dengan langkah-langkah meliputi: inventarisasi ayat-ayat teologis yang digunakan Muktazilah sebagai landasan pokok ideologi mereka (al-ushul al-khamsah). Selanjutnya, penulis mengkaji dan menganalisis penafsiran Ibnu Athiyyah terkait dengan ayat-ayat tersebut untuk melihat ada atau tidaknya bias ideologi dalam penafsiran tersebut. Teknik analisis data yang digunakan adalah metode deskriptif analisis untuk mendeskripsikan dan menganalisis penafsiran Ibnu Athiyyah atas ayat-ayat dijadikan dalil atas prinsip-prinsip dasar akidah Muktazilah.

\section{Hasil dan Pembahasan}

\section{Ibnu Athiyyah Mufassir Adib Andalusia}

Beliau adalah Abu Muhammad Abd al-Haqq bin Ghalib bin Abdurrahman bin Ghalib bin Abdurrauf bin Tamam bin Abdullah bin Tamam bin Athiyyah bin Khalid bin Athiyyah al-Muharibi (Athiyyah, Fahrasat Ibn Athiyyah, 1983); (al-Dzahabi, 2000). ${ }^{1}$ Ibnu Athiyyah lahir di Granada pada tahun $481 \mathrm{H}$ pada masa awal pemerintahan Dinasti Murabithun di Andalusia (Athiyyah, Al-Muharrar al-Wajiz fi Tafsir al-Kitab al-Aziz, 2001). Keluarganya merupakan keluarga bangsawan yang dihormati dan terkenal sebagai pecinta ilmu dan ulama yang banyak memberikan kontribusi keilmuannya di berbagai bidang keislaman, seperti hadis, fikih dan sastra Arab (al-Tilmisani, 1968). Ibnu Athiyyah dikenal sebagai ulama yang cerdas, seorang Imam besar, mufasir yang agung, penyair dan sastrawan yang handal (alKhathib, 2003). Kecerdasannya diwarisi dari orangtuanya ditambah dengan perhatian dan

\footnotetext{
${ }^{1}$ Nama lengkap dan nasab Ibnu Athiyyah ini sesuai dengan yang tertulis dalam Fahrasat Ibn Athiyyah. Para penulis biografi beliau berbeda-beda dalam menuliskan nasabnya, bahkan banyak di antaranya salah dalam menuliskannya. Al-Dzahabi dalam al-Tafsir wa al-Mufassirun ketika menerjemahkan biografi Ibnu Athiyyah hanya menuliskan nama beliau sesuai dengan apa yang ditulis Abu Hayyan, yaitu Abu Muhammad Abd al-Haqq bin Ghalib bin Athiyyah.
} 
kesungguhannya dalam mempelajari dan menelaah kitab-kitab menjadikannya seorang pakar ilmu Islam yang diakui.

Dalam Fahrasatnya, Ibnu Athiyyah menuturkan bahwa kepada sang ayah, Abu Bakar Ghalib bin Athiyyah (w. 518 H), dia belajar kitab Mukhtashar al-Thabari karya Abu Abdillah Muhammad bin Ahmad al-Nahwi (Athiyyah, Fahrasat Ibn Athiyyah, 1983). Ayahnya merupakan pendiri, pengelola dan pengajar sebuah yayasan pendidikan di Granada yang melahirkan banyak sarjana dan ulama (al-Yahshabi, 1982). Melihat banyaknya para pencari ilmu yang datang dari berbagai tempat untuk belajar kepada ayahnya memotivasi Ibnu Athiyyah untuk mempelajari dan menguasai berbagai keilmuan Islam. Kecintaannya terhadap ilmu pengetahuan sudah terlihat sejak kecil. Selain dari ayahnya, Ibnu Athiyyah juga mengambil sanad keilmuan dari Abu Ali al-Ghassani (w. 498 H) seorang ulama hadis yang juga menguasai ilmu bahasa, linguistik dan sastra. Kemudian ia juga berguru kepada Abu Ali al-Husein bin Muhammad al-Shadafi (w. $514 \mathrm{H}$ ) pemimpin ahli hadis setelah meninggalnya Abu Ali al-Ghassani, Abu al-Hasan Ali bin Ahmad al-Anshari (w. 528 H) ahli sastra, bahasa Arab dan ilmu qiraat, Abu Muhammad Abdurrahman bin Muhammad alQurthubi (w. 520 H) seorang ahli fikih dan hukum Islam, Abu Abdillah Muhammad bin Ali al-Taghlabi (w. 508 H), Abu al-Mutharrif Abdurrahman al-Sya'bi (w. 497 H), Abu al-Qasim bin al-Hashshar (w. 511 H), dan lainnya (al-Dzahabi M. b., 2006).

Ibnu Athiyyah hidup pada masa Dinasti Murabithun di Andalus. Ia lahir pada awal masuknya Dinasti Murabithun di Andalusia dan meninggal pada tahun $542 \mathrm{H}$ bersamaan dengan berakhirnya kekuasaan dinasti ini di dunia barat Islam. Selama hidupnya, Ibnu Athiyyah mengalami tiga kali kepemimpinan Daulah Murabithun, yaitu Yusuf bin Tasyfin yang memimpin Dinasti Murabithun hingga tahun $500 \mathrm{H}$, Ali bin Yusuf bin Tasyfin yang menggantikan ayahnya hingga tahun $537 \mathrm{H}$ dan Tasyfin bin Ali bin Yusuf yang menggantikan ayahnya hingga terjadinya peperangan melawan Dinasti Muwahhidun pada tahun 539 H. Di akhir hidupnya Ibnu Athiyyah menyaksikan revolusi Andalusia atas Dinasti Murabithun dan berakhirnya Dinasti tersebut sekaligus awal bagi kekuasaan Dinasti Muwahhidun.

Dalam perjalanan hidupnya, Ibnu Athiyyah mengalami masa puncak keilmuan yang menjadi masa keemasan Andalusia di bawah pemerintahan Dinasti Murabithun. Gerakangerakan keilmuan berkembang pesat dan mencapai puncaknya, sekolah-sekolah sebagai pusat kajian Islam dibuka dan tersebar di berbagai kota seperti Cordoba, Granada, Murcia, Sevilla dan lainnya. Para pencari ilmu berdatangan ke Andalusia dari berbagai daerah, baik dari kawasan masyriq maupun maghrib. 
Kemajuan keilmuan di Andalusia saat itu tidak terlepas dari peran pemerintah Dinasti Murabithun yang sangat intens terhadap perkembangan keilmuan dan pengetahuan. Para pemimpin dari dinasti ini sangat menghormati dan menjalin kedekatan dengan para ahli fikih serta memposisikan fuqaha' sebagai sosok penting yang menduduki Dewan Fatwa Hukum Islam terkait masalah-masalah yang muncul dalam kehidupan masyarakat hingga meminta nasehat dan pendapatnya dalam menjalankan kepemimpinan negara (al-Tilmisani, 1968). Di tengah keharmonisan hubungan antara pemimpin negara dan ulama inilah Ibnu Athiyyah hidup. Perkembangan keilmuan yang pesat membuat Andalusia banyak melahirkan ulama di berbagai bidang keilmuan, seperti fikih, hadis, tafsir, qiraat, ilmu bahasa Arab, nahwu, sejarah dan sastra seni. Ibnu Athiyyah menjadi salah satu tokoh ulama Andalusia masa Daulah Murabithun yang dikenal sebagai ahli bahasa dan qiraat, tafsir dan ilmu al-Qur'an dengan karya tafsirnya al-Muharrar al-Wajiz. Kecerdasan, keilmuan dan ketokohannya mengantarkannya menjadi Qadhi untuk kota Almeria pada bulan Muharram tahun $529 \mathrm{H}$ (al-Abar, 1989).

Kepakaran Ibnu Athiyyah di berbagai disiplin ilmu dan keluasan pengetahuan serta wawasan keilmuannya diakui oleh para penulis biografinya. Ibnu Basykuwal mengatakan: “(Ibnu Athiyyah) adalah seseorang yang memiliki pengetahuan yang luas, literatur yang kuat dan menguasai berbagai disiplin ilmu" (Basykuwal, 1995). Ibnu al-Abar juga mengakui bahwa Ibnu Athiyyah adalah salah satu ulama Andalus yang menguasai fikih, hadis, tafsir dan sastra sekaligus (al-Abar, 1989). Begitu juga Abu al-Hasan al-Nabbahi memuji Ibnu Athiyyah sebagai seorang Qadhi Andalusia yang menguasai hukum, ahli fikih, hadis, tafsir, sastrawan handal, penyair dan ahli bahasa yang mumpuni (al-Nabbahi, 1948).

Ibnu Athiyyah meninggal pada tahun $541 \mathrm{H}$ di kota Luraqah (al-Andalusi, 1983), (alDhabbi, 1914), (al-Tilmisani, 1968), (al-Abar, 1989), ${ }^{2}$ Andalusia dengan meninggalkan beberapa karya, di antaranya: tafsir al-Muharrar al-Wajiz fi Tafsir al-Kitab al-'Aziz, kitab al-Ansab yang mengcounter kitab Iqtibas al-Anwar wa al-Iltimas al-Azhar fi Ansab alSahabah wa Ruwat al-Atsar karya al-Rasyathi, al-Fahrasah dan lainnya.

\footnotetext{
${ }^{2}$ Para sejarawan bersepakat tentang tahun lahir Ibnu Athiyyah, namun mereka berbeda pendapat terkait tahun wafatnya. Abu Hayyan al-Andalusi dalam tafsirnya menukil perkataan Qadhi Ibnu Abi Hamzah bahwa Ibnu Athiyyah meninggal di Luraqah pada 25 Ramadan $541 \mathrm{H}$. Sedangkan dalam Bughyah al-Multamis disebutkan bahwa Ibnu Athiyyah wafat pada tahun 542 dan dalam pendapat lain 541. Sedangkan al-Maqqari menyebutkan bahwa Ibnu Athiyyah wafat pada tahun $546 \mathrm{H}$. Ibnu al-Abar dalam Al-Mu'jam fi Ashhab alQadhi al-Shadafi merajihkan pendapat yang mengatakan wafatnya Ibnu Athiyyah pada tahun $541 \mathrm{H}$.
} 


\section{Sekilas tentang Tafsir al-Muharrar al-Wajiz: Metodologi dan Corak Penafsiran}

Tafsir Ibnu Athiyyah dikenal dengan nama al-Muharrar al-Wajiz fi Tafsir al-Kitab al-'Aziz. Nama ini bukanlah nama yang disematkan Ibnu Athiyyah untuk karya tafsirnya. Para ulama abad ke-6 hingga ke-10 Hijriyah tidak menyebut tafsir Ibnu Athiyyah dengan nama al-Muharrar al-Wajiz fi Tafsir al-Kitab al-'Aziz, sebagian tanpa menyebutkan namanya dan sebagian yang lain menyebutnya dengan tafsir al-Wajiz. Ibnu Umairah alDhabib (w. 599 H) misalnya ketika menulis biografi Ibnu Athiyyah beliau mengatakan bahwa Ibnu Athiyyah menulis sebuah tafsir yang melebihi dari apa yang telah ditulis ulama sebelumnya tanpa menyebut nama tafsirnya (al-Dhabbi, 1914). Pada abad ke-7 misalnya Ibnu al-Abar (w. $658 \mathrm{H}$ ) memuji tafsir Ibnu Athiyyah sebagai karya tafsir yang sangat bermanfaat, banyak dicatat, didengarkan dan dipelajari oleh para penuntut ilmu (al-Abar, 1989). Sedangkan ulama abad ke-8 menggunakan nama al-Wajiz untuk menyebut tafsir Ibnu Athiyyah, misalnya Lisan al-Din bin al-Khathib (w. 776 H) yang menuturkan bahwa Ibnu Athiyyah menulis kitab tafsir yang dinamakan al-Wajiz fi al-Tafsir dengan penjelasan yang sangat bagus dan inspiratif (al-Khathib, 2003). Begitu juga Abu al-Hasan al-Nabahi (w. 800 H) dalam Tarikh Qudhat al-Andalus menyebut tafsir Ibnu Athiyyah dengan nama al-Wajiz fi al-Tafsir (al-Nabbahi, 1948). Judul tafsir Ibnu Athiyyah dengan nama al-Muharrar alWajiz fi Tafsir al-Kitab al-Aziz ini mulai dikenal pada abad ke-11 Hijriyah seperti yang disebutkan oleh Mula Katib al-Jalabi (w 1067 H) yang dinukil oleh Haji Khalifah dalam Kasyf al-Dzunnun (Khalifah, t.t). Hal ini disebabkan karena Ibnu Athiyyah sendiri tidak menyebut sebuah nama khusus untuk tafsirnya, beliau hanya menyampaikan tujuan dan harapannya di awal kitabnya agar kitabnya menjadi sebuah kitab yang jami' wajiz muharrar (Athiyyah, Al-Muharrar al-Wajiz fi Tafsir al-Kitab al-Aziz, 2001).

Sebagaimana para mufassir di Andalusia dan Kawasan Barat Islam (al-Gharb alIslami) yang lain, dalam menulis tafsirnya Ibnu Atiyyah juga terpengaruh oleh pemikiran mufassir masyriq dengan menjadikan karya-karya mereka sebagai rujukan yang hanya tidak terbatas pada karya-karya tafsir saja, namun juga kitab-kitab qiraat, hadis, bahasa, nahwu, fikih, tauhid dan buku-buku sejarah. Di antara kitab-kitab tafsir yang banyak dirujuk Ibnu Athiyyah, yaitu tafsir al-Thabari yang banyak memberikan pengaruh dalam hal perhatiannya dengan tafsir bil ma'tsur; kitab Syifa' al-Shudur karya Abu Bakar al-Naqasy; tafsir alTahshil li Fawaid Kitab al-Tafshil al-Jami' li 'Ulum al-Tanzil karya Abu al-Abbas alMahdawi dan tafsir Makki bin Abi Thalib al-Qaisi.

Adapun kitab-kitab tauhid yang menjadi rujukan Ibnu Athiyyah dalam tafsirnya merupakan kitab-kitab tauhid karya ulama Asy’ariyyah, di antaranya kitab-kitab karya Imam 
Abu al-Hasan Ali bin Ismail al-Asy'ari (w. 334 H), kitab-kitab karya Abu Bakar Muhammad bin al-Thayyib al-Asy'ari al-Baqilani (w. 403 H), kitab-kitab karya Abu al-Ma'ali Abdulmalik bin Abdullah al-Juwaini (w. 478 H) dan lainnya. Karena itulah penjelasanpenjelasan Ibnu Athiyyah terhadap ayat-ayat teologi yang menjadi topic pembahasan penelitian ini banyak merujuk pada kitab-kitab ilmu kalam karya Asy'ariyyah, meskipun Ibnu Athiyyah juga menyebutkan pendapat dari kelompok yang lain seperti Muktazilah dan lainnya sebagaimana nanti akan dipaparkan di bagian pembahasan artikel ini. Sedangkan kitab-kitab sejarah yang menjadi rujukan Ibnu Athiyyah di antaranya Sirah al-Rasul karya Abu Bakar Muhammad bin Ishaq al-Mathlabi (w. 150 H) dan kitab-kitab lainnya.

\section{Munculnya Ideologi Madzhab Teologis dalam Penafsiran}

Sejarah telah menjadi saksi penggunaan al-Qur'an demi kepentingan politik yang dilakukan oleh kelompok Muawiyah dengan mengangkat al-Qur'an di ujung tombak sebagai strategi menghindari kekalahan dari kelompok Ali dalam peristiwa Shiffin. Perundingan damai (tahkim) antara Ali dan Muawiyah yang menjadi akhir dari peristiwa Shiffin justru menjadi awal perpecahan umat Islam dengan munculnya aliran-aliran teologis dalam sejarah Islam. Kubu Ali terpecah menjadi dua kelompok, yaitu Syi'ah yang tetap setia mendukung Ali dan Khawarij yang memberontak atas keputusan tahkim. Pertikaian politik seputar kekhalifahan dan siapa yang lebih berhak menjadi khalifah beralih menjadi pertikaian pemikiran dan keyakinan ideologis. Kelompok Khawarij yang tidak setuju dengan keputusan tahkim mengkafirkan dan berencana melakukan pembunuhan terhadap Ali.

Pemikiran ekstrim yang diyakini kelompok Khawarij ini mendorong lahirnya upayaupaya pemikiran untuk memperbaruhi makna iman, rukun dan syarat yang harus dipenuhi dalam diri seorang mukmin. Perdebatan seputar masalah-masalah akidah seperti hubungan antara islam dan iman, hukum pelaku dosa besar, apakah dia mukmin yang berbuat maksiat atau telah keluar dari Islam serta permasalahan akidah lainnya menjadi faktor yang memicu lahirnya kelompok Murji'ah yang memposisikan diri berlawanan pendapat dengan pihak Khawarij. Selanjutnya sekte-sekte akidah lainnya seperti Muktazilah, Asy'ariyyah dan Maturidiyyah muncul dan berkembang dengan perdebatan pembahasan seputar permasalahan akidah.

Munculnya berbagai ideologi atau madzhab keagamaan ini sangat mempengaruhi perkembangan tafsir al-Qur'an, karena setiap madzhab berusaha mencari dalil untuk mendukung madzhabnya meskipun dengan memaksakan teks al-Qur'an agar selaras dengan pemahaman kelompoknya. Sejak saat itu, setiap kelompok politik dan teologi saling bersaing 
membangun dan mengembangkan pemikiran politik dan teologi mereka sebagai titik tolak kebijakan mereka dengan disandarkan pada al-Qur'an. Masing-masing kelompok menguatkan argumennya dengan mengeksploitasi ayat-ayat al-Qur'an melalui penafsiran yang apologis-tendensius (Subhan, 2014). Toshihiko Izutsu menyatakan bahwa hampir semua konsep pokok dalam teologi Islam diambil langsung dari teks al-Qur'an dan menurutnya banyak kasus terminologi teologis tidak lain merupakan penjelasan skolastik dan teoretik terhadap kata-kata dan frasa dalam al-Qur'an (Izutsu, 2003).

Penafsiran yang bias kepentingan politis dan ideologis ini semakin marak dengan tujuan mencari justifikasi atas ideologi madzhab yang diyakini. Terlebih ketika al-Makmun (w. $218 \mathrm{H}$ ) menetapkan Muktazilah sebagai madzhab resmi negara, perdebatan internal dalam satu disiplin ilmu menambah semaraknya suasana keberpihakan atas pemikiran paham-paham tertentu. Sektarianisme dalam tafsir begitu kental mewarnai produk-produk tafsir ketika itu, sehingga penafsiran al-Qur'an seolah dijadikan sebagai alat legitimasi untuk mendukung kekuasaan atau madzhab tertentu, bukan sebagai upaya aplikatif dalam rangka menjadikan al-Qur'an sebagai petunjuk bagi umat manusia.

Kepentingan politis dan ideologis di balik penafsiran al-Qur'an tersebut menyebabkan munculnya penyimpangan-penyimpangan dalam penafsiran. Abdurrahman al-Akk menyebutkan beberapa faktor yang dapat menyebabkan mufasir terjebak pada paham ideologis sehingga mereka tergelincir dalam penyimpangan penafsiran, yaitu: Pertama: Niat jahat dari para pemalsu riwayat yang menisbahkan perkataan yang mereka buat kepada Nabi atau sahabat untuk mewujudkan tujuan dan keinginan mereka. Kedua: Sebagian mufasir sudah meyakini makna tertentu dari suatu ayat berdasarkan ideologi mereka kemudian menafsirkan ayat tersebut dengan makna sesuai dengan ideologi yang mereka yakini. Ketiga: Sebagian mufasir hanya berpegang kepada makna lughawi tanpa memperhatikan wacana atau discourse dan konteks kalimat pada ayat yang ditafsirkan. Keempat: Relasi kuasa dimana penguasa tertentu melakukan intervensi terhadap tafsir-tafsir yang dapat menguatkan legitimasi kekuasaannya (al-‘Akk, 1986).

Di antara aliran teologis dalam khazanah pemikiran Islam yang banyak mewarnai genre penafsiran al-Qur'an adalah Sunni dan Muktazilah. Kelompok Sunni lebih kuat pada semangat ortodoksi bahwa tidak semua teks-teks dalam al-Qur'an dapat dijejak oleh logika manusia, sedangkan Muktazilah cenderung lebih rasional dan dekonstruktif dengan memutlakkan kebenaran al-Qur'an melalui nalar dan akal. Tafsir al-Kasysyaf karya alZamakhsyari merupakan salah satu representasi produk tafsir dari kalangan Muktazilah, sedangkan Mafatihul Ghaib karya Fakhruddin al-Razi dapat mewakili kelompok Sunni. 


\section{Prinsip Akidah Muktazilah dan Tuduhan I'tizal terhadap Ibnu Athiyyah}

Kaum Muktazilah mentakwilkan ayat-ayat al-Qur'an sesuai dengan prinsip dasar akidahnya dalam karya-karya tafsir dengan tujuan untuk menguatkan pemahanan ideologi yang diyakini.

\section{a. Prinsip Akidah Muktazilah}

Para ulama Muktazilah dan pendukungnya bersepakat atas lima prinsip dasar (alushul al-khamsah) dalam akidah, yaitu: Pertama: Tauhid sebagai inti akidah madzhab Muktazilah. Atas dasar prinsip tauhid ini, mereka membangun keyakinan tentang mustahil melihat Allah di akhirat, sifat-sifat Allah adalah substansi Dzat Allah sendiri dan bahwa alQur'an adalah makhluk. Kedua: Prinsip keadilan, bahwa Allah tidak menghendaki dan tidak menciptakan semua makhluk yang ada di alam ini serta tidak mampu atasnya. Bahkan menurut mereka semua perbuatan manusia ( af'al al- 'ibad) tidaklah diciptakan oleh Allah, Allah tidak menghendaki apapun juga kecuali apa yang telah diperintahkanNya.

Ketiga: Janji dan ancaman (al-wa'du wa al-wa'id) bahwa Allah akan memberikan balasan kepada orang yang melakukan kebaikan dan hukuman bagi orang yang melakukan perbuatan buruk. Allah berkewajiban memberi pahala kepada orang yang taat dan menyiksa para pelaku dosa besar. Allah tidak mengampuni pelaku dosa besar jika tidak bertaubat. Pelaku dosa besar juga tidak mendapatkan syafaat dan kekal di neraka selama-lamanya dengan berdalil pada Q.S. al-Baqarah: 81. Pemberian balasan pahala dan siksa bersifat wajib bagi Allah. Keempat: Tempat di antara surga dan neraka (al-manzilah baina al-manzilatain). Seorang muslim yang berbuat dosa besar maka dia bukan mukmin dan bukan kafir namun disebut fasiq, jika meninggal dunia sebelum bertaubat maka akan masuk neraka selamalamanya, karena di akhirat kelak hanya ada dua golongan: golongan yang masuk surga dan golongan masuk neraka.

Kelima: Amar makruf nahi munkar, menurut mereka prinsip yang kelima ini wajib dilakukan dalam menyebarkan dakwah Islam, namun mereka bertindak berlebih-lebihan dan berselisih pandangan dengan mayoritas ulama. Mereka mengatakan bahwa amar makruf nahi munkar ini dilakukan dengan hati saja, bila tidak cukup maka dengan lisan, jika tidak cukup maka dengan tangan dan jika tidak cukup maka dengan senjata dengan berdalil pada Q.S al-Hujurat: 9. Dalam hal ini mereka tidak pandang bulu antara penguasa dengan rakyat biasa (al-Dzahabi M. a.-S., 2000), (Faudah, 1987).

Muktazilah menggunakan kelima prinsip dasar ini untuk mengcounter pendapat ulama Sunni, karena itu mereka menguatkannya dengan dalil-dalil al-Qur'an yang disesuaikan penafsirannya dengan paham teologis yang mereka yakini. Eksploitasi ayat-ayat 
al-Qur'an dilakukan dengan menggunakan akal dan nalar yang dominan dari pada atsar dalam praktik penafsiran. Sebagai konsekuensinya mereka mengingkari hadis-hadis Nabi yang berlawanan dengan prinsip dan paham teologis mereka meskipun hadis tersebut merupakan hadis yang shahih.

\section{b. Tuduhan I'tizal terhadap Ibnu Athiyyah}

Setidaknya ada dua tokoh besar yang menuduh bahwa tafsir Ibnu Athiyyah mendukung pemahaman Muktazilah, yaitu: Pertama, Ibnu Taimiyyah (w. $728 \mathrm{H}$ ) dalam kitabnya yang berjudul Muqaddimah fi Ushul al-Tafsir menyatakan bahwa meskipun tafsir Ibnu Athiyyah mengikuti pemahaman Ahlussunnah waljama'ah dan lebih terbebas dari bid'ah penafsiran jika dibandingkan dengan al-Kasysyaf, namun Ibnu Athiyyah sering menukil perkataan Imam al-Thabari dalam tafsirnya namun tidak menjelaskannya secara persis seperti yang tertulis dalam tafsir al-Thabari, kemudian menyebut apa yang menjadi anggapan pemahamannya sebagai qaul al-muhaqqiqin (perkataan orang-orang yang benar), padahal yang dia maksud adalah kelompok ahli kalam yang menetapkan ushul (prinsip) mereka sesuai dengan apa yang ditetapkan oleh golongan Muktazilah (Taimiyyah, 1355H).

Kedua, Ahmad bin Hajar al-Haitami (w. 973 H) yang dengan tegas menyatakan dalam kitabnya Fatawa al-Haditsiyyah bahwa dalam tafsir Ibnu Athiyyah terdapat pemahaman Muktazilah. Al-Haitami juga menukil komentar Ibnu 'Arafah (w. 803 H) bahwa tafsir Ibnu Athiyyah lebih mengkhawatirkan bagi pelajar pemula dari pada al-Kasysyaf, karena al-Kasysyaf sudah dikenal sebagai tafsir yang memuat bid'ah-bid'ah penafsiran, pemahaman Muktazilah dan menyalahi kebenaran sehingga orang-orang menghindarinya. Berbeda dengan Ibnu Athiyyah yang dikenal sebagai seorang yang Sunni, namun masih memasukkan dan menetapkan sebagian pemahaman Muktazilah dalam tafsirnya tanpa memberikan peringatan, sehingga menyebabkan pemahaman tersebut dianggap sebagai pemahaman Ahlussunnah. Hal ini lebih berbahaya dari pada kitab al-Kasysyaf (al-Haitami, t.t.).

Dari sini dapat dipahami bahwa menurut Ibnu Taimiyyah, tafsir Ibnu Athiyyah memuat sebagian pemahaman dan prinsip-prinsip Muktazilah, namun tafsir Ibnu Athiyyah lebih baik daripada tafsir al-Kasysyaf, karena secara global mengikuti pemahaman ahlussunnah waljama'ah dan lebih terhindar dari bid'ah-bid'ah penafsiran. Sebaliknya Ibnu 'Arafah beranggapan bahwa tafsir Ibnu Athiyyah lebih membahayakan dari pada tafsir alKasysyaf, sebab al-Zamakhsyari dikenal sebagai penganut Muktazilah sehingga orang-orang lebih berhati-hati, berbeda dengan Ibnu Athiyyah yang dikenal sebagai tokoh Sunni, namun menyelipkan Muktazilah dalam tafsirnya tanpa memberikan peringatan terhadapnya, 
sehingga hal ini rawan disalahpahami bagi yang mempelajari tafsirnya dengan menganggapnya sebagai pemahaman ahlussunnah, padahal bukan. Oleh karena itu, menurut Ibnu 'Arafah tafsir Ibnu Athiyyah lebih berbahaya bagi akidah masyarakat, terlebih para kaum pelajar pemula.

Masing-masing dari Ibnu Taimiyyah dan al-Haitami dengan menukil pendapat Ibnu 'Arafah sama-sama melontarkan tuduhan i'tizal kepada Ibnu Athiyyah, meskipun keduanya berbeda dalam hal mana di antara tafsir Ibnu Athiyyah dan tafsir al-Kasysyaf yang lebih berbahaya? Dari sini, penulis akan memaparkan penafsiran-penafsiran Ibnu Athiyyah dalam al-Muharrar al-Wajiz terhadap ayat-ayat yang sering dikaitkan dengan ushul (prinsip) Muktazilah untuk dapat dicermati dan disimpulkan apakah penafsiran Ibnu Athiyyah mendukung pemahaman prinsip-prinsip ushul Muktazilah atau tidak, atau malah justru menguatkan pendapat Ahlussunnah.

\section{Sikap Ibnu Athiyyah terhadap Ushul Akidah Muktazilah dalam al-Muharrar al-} Wajiz

a. Prinsip Akidah Pertama (Tauhid: Dzat dan Sifat-sifat Allah, Kalamullah dan Ru'yatullah)

Terkait dengan prinsip akidah yang pertama bagi Muktazilah yaitu tauhid, Ibnu Athiyyah menetapkan akidah Sunni dalam penafsirannya baik tentang Dzat Allah ataupun sifat-sifat Allah, seperti bahwa tidak ada sesuatupun yang menyerupai Allah, Allah bukanlah jism dan tidak menempati ruang, Allah Maha Suci dari tertangkap oleh panca indera, tasybih (penyerupaan) dan takyif (kriteria). Ibnu Athiyyah menguatkan pendapatnya dengan menukil perkataan ulama Sunni seperti Asy'ari, Baqilani dan Imam al-Haramain.

Tentang ayat-ayat yang secara zahir menyatakan bahwa Allah menempati ruang dan arah atau dibatasi oleh zaman (waktu), maka Ibnu Athiyyah mengarahkannya kepada penafsiran yang sesuai dengan prinsip akidah Ahlussunnah yaitu wajibnya al-tanzih al-tam (penyucian yang sempurna) atas Dzat Allah. Misalnya ketika menafsirkan ayat 29 surat alBaqarah, Ibnu Athiyyah menafsirkan lafadz istawa dengan sesuatu yang jauh dari makna zaman (waktu) dan makan (tempat) yang mustahil bagi Allah SWT.

Ibnu Athiyyah memulai penafsirannya terhadap ayat 29 surat Al-Baqarah dengan melakukan analisa linguistik dengan menyatakan bahwa lafadz tsumma pada ayat tersebut menunjukkan urutan kabar berita bukan urutan Dzat Allah itu sendiri, kemudian menjelaskan makna lafadz istawa dengan menukil pendapat al-Thabari bahwa istawa di sini bermakna tinggi tanpa ada kriteria dan batasan, jadi dzat, kekuasaan dan wewenang Allah itu Maha 
Tinggi. Selain itu, Ibnu Athiyyah berpendapat bahwa istawa juga mempunyai makna istawla (menguasai/memerintah) dengan berdalil pada sebuah syair Arab: "Manusia telah menguasai kota Irak, tanpa angkat senjata dan darah yang mengalir." Makna istawla untuk kata istawa ini sebagaimana pada Q.S. Thaha: 5, dan prinsip memaknai lafadz istawa pada ayat-ayat alQur'an adalah tidak menunjukkan perpindahan tempat dan hal-hal lain yang berlaku pada hawadits (ciptaan Allah).

Dalam menafsirkan ayat 'ala al- 'arsy istawa pada Q.S. al-An'am: 3, Ibnu Athiyyah menyatakan bahwa kaidah yang berlaku dalam ayat ini adalah mustahilnya Allah berpindah tempat dan mengambil tempat pada makhluk (al-hawadits). Sedangkan ayat wahuwa Allah fi al-samawa.t wa fi al-ardh ya'lamu sirrakum wajahrakum waya'lamu ma taksibun menegaskan bahwa mustahil bagi Allah mengambil tempat dalam ruang dan arah karena mustahilnya al-ta'addud bagi Allah.

Adapun kata al-fauqiyyah pada Q.S. al-Nahl: 50 menurut Ibnu Athiyyah berarti dua hal: Pertama, al-fauqiyyah yang disandarkan kepada Allah merupakan fauqiyyah (atas/tinggi) dalam kekuasaan, keagungan, kekuatan dan kewenangan, bukan fauqiyyah yang menunjukkan arah ataupun tempat. Karena itu, ayat yakhafuna rabbahum min fauqihim wayaf'aluna ma yu'marun mengandung dua kemungkinan makna, bahwa mereka takut akan kekuasaan, keagungan, kekuatan dan kewenangan Tuhannya atau mereka takut akan siksa Tuhan yang biasanya datang dari atas mereka.

Ayat-ayat yang secara dzahir menunjukkan adanya penyerupaan Allah terhadap makhluk seperti penyandaran wajah, tangan atau mata, maka Ibnu Athiyyah menyebutkan pendapat ulama ahlussunnah, seperti ketika menafsirkan Q.S. al-Maidah: 64 mengatakan bahwa akidah dalam ayat ini bermakna meniadakan penyerupaan terhadap Allah, bahwa Allah bukanlah jism yang memiliki anggota badan, Dia tidak menyerupai apapun, tidak memiliki kriteria, tidak menempati ruang dan tidak ada makhluk yang mengambil tempat (menyatu) padanya. Maha Suci Allah dari perkataan orang-orang yang batil.

Selanjutnya Ibnu Athiyyah menyebutkan pendapat-pendapat para ulama ahlussunnah terkait makna bal yadahu mabsuthatani, biyadayya, 'amilat aidina, yad Allah fawqa aidihim, litushna'a 'ala 'aini, tajri bia'yunina, ishbir lihukmi rabbika fainnaka bia'yunina, kullu syai'un halikun illa wajhah yang terbagi menjadi tiga pendapat; Pertama; sebagian ulama di antaranya al-Sya'bi, Ibnu al-Musayyab dan Sufyan berpendapat bahwa kita mengimani hal-hal tersebut dan menetapkan apa yang Allah tetapkan dalam al-Qur'an tanpa memberikan penafsiran ataupun mempelajarinya. Kedua; pendapat Jumhur al-ummah di antaranya madzhab Imam Abu al-Ma'ali al-Juwaini dan al-Hadzdzaq yang menyatakan 
bahwa ayat-ayat tersebut ditafsirkan sesuai dengan kaidah bahasa Arab, majaz, metafora, dan sastra Arab lainnya. Kata 'ain diartikan sebagai ungkapan tentang ilmu dan pengetahuan, wajh berarti dzat dan sifat-Nya, sedangkan yad/yadain terkadang bermakna kekuasaan (qudrah) dan terkadang bermakna nikmat. Makna-makna ini ketika ditujukan pada Allah maka digunakan kata yad atau al-aidi atau yadain karena fashahah al-'Arab dan karena lebih sederhana (ijaz) dalam pemakaiannya. Ketiga; pendapat ulama di antaranya al-Thabari dan al-Qadhi bin al-Thayyib yang mengatakan bahwa semua sifat tersebut adalah sifat zaidah 'ala al-dzat, tsabitah bagi Allah tanpa adanya penyerupaan ataupun pembatasan (Athiyyah, Al-Muharrar al-Wajiz fi Tafsir al-Kitab al-Aziz, 2001).”

Dari sini dapat kita pahami bahwa Ibnu Athiyyah memaparkan pendapat-pendapat ulama Ahlussunnah dalam hal ini yang dapat dikelompokkan menjadi 3 pendapat utama, yaitu: pertama; pendapat yang mengatakan al-tafwidh, yakni beriman pada hal-hal tersebut dan tidak membahas maknanya serta menyerahkan sepenuhnya kepada Allah. Kedua; pendapat yang mengatakan takwil, bahwa kita menakwilkan ayat-ayat tersebut dengan makna yang sesuai dengan kaidah-kaidah bahasa Arab dalam hal majaz dan metafora. Di antara yang mengamini pendapat ini adalah Imam al-Juwaini. Ketiga; pendapat yang mengatakan al-itsbat, bahwa kita menetapkan hal-hal tersebut sebagai sifat zaidah 'ala aldzat, tsabitah bagi Allah tanpa adanya penyerupaan, batasan ataupun kriteria. Dari sini dapat kita simpulkan bahwa Ibnu Athiyyah tidak sependapat dengan kelompok yang menyatakan tafwidh dan lebih condong pada pendapat takwil, terlihat dari penyebutannya dengan qaul al-jumhur dan madzhab al-ummah.

Ketika menafsirkan ayat "walillah al-masyriq wa al-maghrib faainama tuwallu fatsamma wajh Allah inna Allah wasi' 'alim” Ibnu Athiyyah menyebutkan pendapat yang menyatakan takwil dan itsbat dengan menunjukkan kelemahan pendapat yang mengatakan itsbat dan tidak menyinggung pendapat tentang tafwidh karena menurutnya pendapat ini merupakan pendapat yang lemah (Athiyyah, Al-Muharrar al-Wajiz fi Tafsir al-Kitab al-Aziz, 2001). Senada dengan hal ini, dalam menafsirkan ayat "washna' al-fulk bia'yunina wawahyina" hanya menyebutkan pendapat yang menyatakan takwil karena menurutnya pendapat inilah yang paling rajih (kuat). Kata bia'yunina ditakwilkan dengan ungkapan dari pengetahuan, perlindungan serta penjagaan dan pemakaian kata jamak dimaksudkan untuk mengagungkan, bukan untuk menunjukkan makna banyak. Sehingga makna al-a'yun dalam ayat ini dan ayat-ayat lainnya merujuk pada kata 'aini dalam Q.S. Thaha: 39, “walitushna'a 'ala 'aini” yang menunjukkan pada makna pengetahuan Allah meliputi segalanya dan Maha Suci Allah dari panca indera, tasybih dan takyif. Ayat "bia'yunina” bisa juga diartikan 
dengan malaikat-malaikat Kami yang telah kami berikan mata untuk menjaga dan membantumu, sehingga pemakaian jamak di sini menunjukkan makna banyak (li al-taktsir) (Athiyyah, Al-Muharrar al-Wajiz fi Tafsir al-Kitab al-Aziz, 2001).

Berkaitan dengan perbedaan antara Ahlussunnah dan Muktazilah tentang apakah sifat-sifat qadim Allah itu tsabitah lillah atau manfiyyah 'anh? Apakah kalamullah itu bersifat qadim atau hadis dan makhluk? Dan apakah ru'yatullah itu jaiz atau mustahil? Maka kita dapati bahwa dalam tiga masalah pokok ini Ibnu Athiyyah sepakat dengan ulama Ahlussunnah dan menyelisihi Muktazilah.

Terkait dengan sifat qadim Allah, Ibnu Athiyyah menyatakan itsbat sebagaimana madzhab Ahlussunnah dan mengcounter Muktazilah yang menafikannya. Ketika menafsirkan ayat "walau yara al-ladzina zhalamu> idz yarauna al-'adzaba anna alquwwata lillahi jami'a” Ibnu Athiyyah menetapkan sifat kuat yang berarti kekuasaan (alqudrah) bagi Allah dan mengatakan bahwa nash ayat ini menetapkan sifat kuat bagi Allah, berbeda dengan perkataan Muktazilah yang meniadakan sifat ma'ani sebagai sifat qadim bagi Allah (Athiyyah, Al-Muharrar al-Wajiz fi Tafsir al-Kitab al-Aziz, 2001). Begitu juga ketika menafsirkan ayat "Allahu la ilaha illa huwa al-hayyu al-qayyum la ta'khudzuhu sinat wa la naum" Ibnu Athiyyah menetapkan sifat hayat bagi Allah sebagaimana madzhab Ahlussunnah dan menjelaskan bahwasanya pendapat Muktazilah yang menyebutkan bahwa Allah Maha Hidup (hayy) tanpa sifat hayat merupakan pendapat yang ditinggalkan (Athiyyah, Al-Muharrar al-Wajiz fi Tafsir al-Kitab al-Aziz, 2001).

Selanjutnya, Ibnu Athiyyah menyebutkan bahwa ayat "lakinna Allahu yashhadu bima anzala ilaika anzalahu bi'ilmih wa al-malaikatu yasyhadun” merupakan dalil yang paling kuat atas penetapan sifat al-'ilm bagi Allah, berbeda dengan Muktazilah yang mengatakan bahwa Allah itu 'alim bila 'ilm (Maha Mengetahui tanpa sifat ilmu). Menurut Ahlussunnah ayat ini menjelaskan tentang sifat al-ilm bagi Allah, Allah yang menurunkan al-Qur`an dan mengetahui proses turunnya, baik saat diturunkan secara keseluruhan maupun secara bertahap. Berbeda dengan madzhab Muktazilah yang mengatakan bahwa Allah menurunkan al-Qur`an bersamaan dengan ilm-Nya.

\section{Pendapat Ibnu Athiyyah tentang Kalamullah}

Ibnu Athiyyah menjelaskan bahwa kalamullah merupakan makna yang melekat pada Dzat Allah, bersifat qadim, tidak bersifat huduts (baru) dan tidak berupa suara. Pendapat Ibnu Athiyyah ini sejalan dengan akidah Ahlussunnah terkait al-Qur'an, yaitu bahwa alQur'an adalah kalamullah yang bersifat qadim, berbeda dengan madzhab Muktazilah yang 
menyatakan bahwa al-Qur'an bersifat huduts dan makhluk. Dalam ayat "wakallama Allah musa taklima” Ibnu Athiyyah berkata: "Dan kalam Allah kepada Nabi tidak menerima kriteria, batasan, tidak bersifat baru, tidak berbentuk huruf ataupun suara. Allah menciptakan idrak (pengetahuan) bagi Musa dan Jibril melalui pendengaran yang dengannya kalam itu ada. Allah itu ada tapi tidak seperti maujudat yang lain, ma'lum tapi tidak seperti ma 'lumat yang lain, begitu juga kalam Allah tidak seperti kalam yang lain” (Athiyyah, Al-Muharrar al-Wajiz fi Tafsir al-Kitab al-Aziz, 2001).

Penolakan Ibnu Athiyyah terhadap pemahaman Muktazilah juga terlihat saat ia membantah pernyataan Abu Ali al-Farisi yang menafikan adanya kalam qadim azali bagi Allah ketika menafsirkan ayat "waidza qadha amran fainnama yaqulu lahu kun fayakun". Ibnu Athiyyah menyatakan bahwa apa yang disampaikan Abu Ali bahwa lafadz qadha bermakna amdha ketika penciptaan adalah pendapat yang rancu dan itu merupakan pendapat Muktazilah (Athiyyah, Al-Muharrar al-Wajiz fi Tafsir al-Kitab al-Aziz, 2001). Di sini Ibnu Athiyyah terlihat menetapkan pendapat Ahlussunnah dan mengkritik madzhab Muktazilah. Namun dalam ayat "inna matsala 'isa 'inda Allahi kamatsal adam khalaqahu min turab tsumma qala lahu kun fayakun" Ibnu Athiyyah menyebutkan pendapat madzhab Ahlussunnah dan Muktazilah tanpa menyatakan ataupun menjelaskan kesalahan pemahaman Muktazilah. Oleh karena itu, tidak benar tuduhan yang mengatakan bahwa Ibnu Athiyyah memasukkan pemahaman Muktazilah dalam tafsirnya, kemudian membenarkan dan tidak mengingatkan kekeliruaan pendapat tersebut. Akan tetapi Ibnu Athiyyah telah menjelaskan kesalahan pendapat Muktazilah tersebut ketika menafsirkan ayat lainnya, hanya saja dalam ayat ini Ibnu Athiyyah hanya menyebutkan kedua madzhab tanpa menjelaskan kesalahan pendapat Muktazilah. Menurut penulis Ibnu Athiyyah telah mencukupkan penjelasan ketidakbenaran pendapat Muktazilah tersebut pada ayat-ayat yang lain.

\section{Pemahaman tentang $R u^{\prime}$ yatullah}

Adapun terkait ru'yatullah Ibnu Athiyyah dalam tafsirnya menyebutkan pendapat dari Ahlussunnah dan Muktazilah serta dalil yang digunakan dari keduanya kemudian membenarkan pendapat Ahlussunnah dan mengkritik pendapat Muktazilah, seperti ketika menafsirkan ayat "la tudrikuhu al-abshar wahuwa yudrik al-abshar wahuwa al-lathif alkhabir Ibnu Athiyyah mengatakan: "Ulama Ahlussunnah telah sepakat bahwa orang-orang mukmin akan melihat Allah pada hari kiamat. Pendapat ini disampaikan oleh Ibnu Wahb dari Malik bin Anas. Pendapat ini dapat diterima oleh akal dan dibenarkan secara logika ditambah dengan adanya nash yang membolehkan terjadinya ru'yatullah tersebut. 
Sebagaimana kita mengetahui bahwa Allah tidak berada di suatu tempat tertentu, tidak menempati ruang dan pengetahuan kita tersebut hanya berkaitan dengan wujudnya Allah maka begitu juga kita dapat melihatNya tanpa berhadapan dan tanpa adanya kriteria serta batasan-batasan tertentu" (Athiyyah, Al-Muharrar al-Wajiz fi Tafsir al-Kitab al-Aziz, 2001).

Selanjutnya Ibnu Athiyyah menukil perkataan Abu Abdillah al-Nahwi bahwa lafaz al-nazhr yang didahului dengan ila pada Q.S. al-Qiyamah: 12-13 "wujuhun yaumaidzin nadhirah ila rabbiha nazhirah" dalam kalam Arab bermakna ru'yah (melihat), bukan bermakna intizhar (menunggu) sebagaimana yang dipahami kaum Muktazilah. Hal ini sesuai dengan sabda Nabi: "innakum tarauna rabbakum yaum al-qiyamah kama tarauna al-qamar lailat al-badr" (al-Bukhari, 1422H). ${ }^{3}$ Muktazilah menguatkan pendapat mereka tentang mustahilnya ru'yatullah pada ayat "la tudrikuhu al-abshar". Sedangkan Ahlussunnah menyatakan bahwa ayat ini ditujukan khusus untuk ru'yah di dunia dan ru'yah di akhirat dibenarkan dengan nash-nash al-Qur'an dan hadis.

Dalam hal ru'yatullah ini dapat kita lihat bahwa Ibnu athiyyah memberikan beberapa sanggahan atas pendapat Muktazilah, di antaranya: dalil Muktazilah bahwa jika Allah dapat dilihat, maka ini berarti Allah berada pada posisi yang berhadapan dengan subjek yang melihat, Allah menempati ruang dan Allah berada pada suatu tempat. Ibnu Athiyyah menyanggahnya dengan argumen bahwa ru'yatullah tidak berimplikasi pada hal-hal tersebut dan memberikan perumpaan dengan masalah 'ilm kita pada Allah. Sebagaimana kita mengetahui bahwa Allah tidak berada pada suatu tempat, tidak menempati ruang tertentu dan tidak berhadapan, maka kita juga bisa melihat Allah tanpa harus berhadapan, tanpa bertempat dan tanpa batasan.

Ibnu Athiyyah menyanggah penafsiran Muktazilah bahwa al-nazhr bermakna alintizhar (menunggu) bahwa dalam kaidah bahasa Arab ketika lafaz al-nazhr disandingkan dengan ila maka ia bermakna ru'yah (melihat) bukan intizhar (menunggu). Ibnu Athiyyah membatalkan wajh istidlal (dasar pengambilan dalil) Muktazilah terhadap ayat "la tudrikuhu al-abshar" dengan dua argumen: pertama bahwa kandungan makna ayat tersebut khusus di dunia saja, maka Allah tidak bisa ditangkap oleh indera penglihatan manusia di dunia, namun dapat dilihat di akhirat sebagaimana disampaikan hadis-hadis Nabi. Kedua, kita harus membedakan antara idrak dan ru'yah. Idrak berarti pengetahuan yang menyeluruh terhadap sesuatu dari berbagai arah dan hal ini tidak terjadi pada Allah. Adapun ru'yah tidak

\footnotetext{
${ }^{3}$ Hadis ini diriwayatkan oleh Imam al-Bukhari dalam Shahih Bukhari, Kitab al-Tauhid, Bab Qaulullah Ta'ala “wujuhun yaumaidzin nadhrah ila rabbiha nazhirah”, jilid. 9, 156.
} 
mengandung makna pengetahuan yang menyeluruh dan dapat terjadi pada Allah, sehingga dapat dikatakan bahwa Allah yura wala yudrak.

Dalam menafsirkan ayat "li alladzina ahsanu al-husna waziyadah" Ibnu Athiyyah berkata: "Kelompok jumhur mengatakan bahwa al-husna bermakna surga dan al-ziyadah berarti melihat Allah swt. Hal ini sejalan dengan hadis Nabi yang diriwayatkan oleh Shuhaib dari Abu Bakr, Hudzaifah, Abu Musa al-Asy'ari, 'Amir bin Sa'd dan Abdurrahman bin Abi Ya'la. Sedangkan Ali bin Abi Thalib meriwayatkan bahwa Nabi berkata: "al-ziyadah (tambahan) berarti kamar dari mutiara." Kelompok lain berkata bahwa al-husna berarti kebaikan dan al-ziyadah berarti kebaikan yang dilipatgandakan menjadi 700 kali sebagaimana disebutkan dalam hadis dan ayat "wa Allahu yudha'ifu liman yasya".. Ibnu Athiyyah lalu menyatakan bahwa pendapat kelompok terakhir ini lebih sesuai dengan logika nalar, jika bukan karena agungnya para tokoh kelompok pertama, maka pendapat kelompok ketiga (terakhir) inilah yang lebih kuat. Hal ini juga dikuatkan dengan ayat "ulaika ashhab al-nar hum fiha khalidun” pada Q.S. Yunus: 26. Jika al-husna bermakna al-jannah, maka terjadi pengulangan, sehingga maknanya bukanlah balasan surga bagi orang-orang yang berbuat baik dan bahwa wajah mereka tidak ditutupi debu hitam serta kehinaan (Athiyyah, Al-Muharrar al-Wajiz fi Tafsir al-Kitab al-Aziz, 2001).

Perkataan Ibnu Athiyyah inilah yang menurut al-Dzahabi menjadi dasar Ibnu Taimiyyah atas pernyataan bahwa Ibnu Athiyyah lebih memihak pada pendapat Muktazilah yang mengingkari adanya ru'yatullah (al-Dzahabi M. a.-S., 2000), begitu juga dengan Abu Bakar al-Haitami serta Ibnu 'Arafah atas tuduhan i'tizalnya kepada Ibnu Athiyyah. Berdasarkan penjelasan dan penafsiran Ibnu Athiyyah atas ayat-ayat ru'yah dapat kita simpulkan bahwa Ibnu Athiyyah menyatakan bolehnya ru'yatullah di akhirat kelak sebagaimana pendapat Ahlussunnah. Adapun pendapat Ibnu Athiyyah terkait ayat 261 S. alBaqarah, menurut hemat penulis Ibnu Athiyyah berpendapat bahwa ayat ini bukanlah nash kunci dalam masalah ru'yah dan tidak bisa dijadikan dalil ru'yah di akhirat. Sedangkan ayatayat yang dapat dijadikan dalil atas bolehnya ru'yatullah di akhirat, Ibnu Athiyyah telah menjelaskan pendapat-pendapat Ahlussunnah dan Muktazilah serta menguatkan pendapat Ahlussunnah sebagaimana yang telah dijelaskan di atas.

Oleh karena itu, dapat kita simpulkan bahwa terkait prinsip pertama Muktazilah yaitu tauhid, Ibnu Athiyyah dalam tafsirnya sejalan dengan madzhab Ahlussunnah. Ibnu Athiyyah merajihkan madzhab Ahlussunnah tentang tauhid yang berkaitan dengan Dzat Allah dan sifat-sifatnya serta menyebutkan madzhab Muktazilah dengan disertai sanggahan atas 
Muktazilah kecuali di beberapa bagian saja. Hal itu tidak lain karena beliau sudah merasa cukup dengan sanggahan-sanggahan yang telah disampaikannya di bagian-bagian yang lain.

\section{b. Prinsip Akidah Kedua: Keadilan Allah}

Prinsip kedua dari ushul Muktazilah yaitu konsep keadilan Allah. Dalam hal ini penulis akan menyebutkan beberapa pendapat Muktazilah dan respon Ibnu Athiyyah dalam tafsirnya al-Muharrar al-Wajiz terhadap pendapat tersebut.

1. Kelompok Muktazilah berpendapat bahwa Allah tidak menghendaki terjadinya maksiat. Dalam tafsirnya Ibnu Athiyyah menolak pendapat tersebut dan menyatakan bahwa segala sesuatu tidak akan terjadi kecuali atas kehendak Allah, baik itu ketaatan ataupun kemaksiatan. Seperti ketika menafsirkan Q.S. al-An'am ayat 125, Ibnu Athiyyah mengatakan bahwa ayat ini merupakakan bukti bahwa Allah menghendaki petunjuk bagi orang mukmin dan kesesatan bagi orang kafir. Menurut Ahlussunnah kehendak ini dinamakan iradah qadimah yang merupakan sifat dzatiyah bagi Allah (Athiyyah, AlMuharrar al-Wajiz fi Tafsir al-Kitab al-Aziz, 2001). Senada dengan ini, Ibnu Athiyyah juga menafsirkan Q.S. al-An'am: 148 dengan memaparkan pendapat Ahlussunnah dan sanggahan atas pendapat Muktazilah: "Allah memberitahu Nabi-Nya SAW bahwa kaum musyrik akan beralasan untuk membenarkan perbuatan syirik mereka dengan pernyataan bahwa Allah menghendaki perbuatan syirik tersebut dan jika Allah berkehendak selain kesyirikan mereka, maka Allah tidak akan membiarkan mereka dalam kondisi kesyirikan" (Athiyyah, Al-Muharrar al-Wajiz fi Tafsir al-Kitab al-Aziz, 2001). Ibnu Athiyyah juga menjelaskan bahwa tidak ada alasan yang dapat membenarkan atas apa yang dikatakan kaum musyrik, karena meskipun Allah menghendaki kesyirikan mereka, namun Allah memberikan kemampuan kepadanya untuk melakukan perbuatan syirik dan bermaksiat kepada Allah, lalu mengaitkan siksa dan balasan atas perbuatan mereka sebagaimana dimaksud Q.S. al-Taubah: 95 “jazaan bima kanu yaksibun” (Athiyyah, AlMuharrar al-Wajiz fi Tafsir al-Kitab al-Aziz, 2001). Untuk menguatkan pendapatnya tersebut, Ibnu Athiyyah di menafsirkan ayat "waradhitu lakum al-islama dina" bahwa Allah menghendaki dan meridhai Islam sebagai agama bagi kita, namun ada juga hal-hal lainnya yang Allah kehendaki terjadi namun tidak Allah ridhai (Athiyyah, Al-Muharrar al-Wajiz fi Tafsir al-Kitab al-Aziz, 2001).

2. Terkait dengan pendapat Muktazilah bahwa harta haram bukanlah rizki, Ibnu Athiyyah menyatakan dalam penafsirannya terhadap ayat-ayat yang menjelaskan tentang rizki yang Allah berikan kepada manusia bahwa rizki adalah segala sesuatu yang dapat 
dimanfaatkan baik itu halal ataupun haram (Athiyyah, Al-Muharrar al-Wajiz fi Tafsir alKitab al-Aziz, 2001). ${ }^{4}$ Hal ini sesuai dengan madzhab Ahlussunnah.

3. Selanjutnya pendapat Mu'tazilah tentang wujub al-shalah 'ala Allah (Allah harus melakukan yang baik), secara tegas Ibnu Athiyyah membantah bahwa hal itu tidak wajib bagi Allah, sebab Allah bisa memilih untuk melakukan atau tidak melakukan sebagaimana akidah Ahlussunnah dan sesuai dengan Q.S. al-Qashsash: 68 "inna Allah yakhluq ma yasya' wa yakhtar" (Athiyyah, Al-Muharrar al-Wajiz fi Tafsir al-Kitab alAziz, 2001). Dalam menafsirkan Q.S. Ali Imran: 3 Ibnu Athiyyah juga menolak pendapat wajibnya al-shalah bagi Allah dan menjelaskan bahwa lafadz bi al-haqq dalam ayat mengandung dua makna: pertama: al-haqq di sini mencakup khabar, perintah, larangan dan anjuran. Kedua: Allah menurunkan al-Qur'an karena al-Qur'an memuat kemashlahatan yang menyeluruh, akan tetapi bukan berarti hal itu wajib bagi Allah, namun Allah berhak untuk melakukannya (Athiyyah, Al-Muharrar al-Wajiz fi Tafsir alKitab al-Aziz, 2001). Lebih jelas lagi Ibnu Athiyyah menyatakan bahwa ulama Ahlussunnah telah sepakat bahwa Allah tidak wajib melakukan apapun secara nalar logika, namun secara sam'i mereka berbeda pendapat dan ia menyebutkan perbedaan pendapat tersebut dengan rinci (Athiyyah, Al-Muharrar al-Wajiz fi Tafsir al-Kitab alAziz, 2001).

4. Ibnu Athiyyah juga menolak pendapat Muktazilah terkait al-tahsin wa al-taqbih al'aqlain dan menegaskan bahwa akal tidak dapat menghukumi baik ataupun buruk, namun syariatlah yang dapat melakukannya. Sebagai contohnya ketika menafsirkan Q.S al-Baqarah: 169, Ibnu Athiyyah mengatakan bahwa asalnya kata al-fahsya' berarti yang tidak enak dipandang, lalu digunakan untuk menyebutkan hal-hal yang bermakna buruk, dan syariatlah yang menghukumi baik atau buruk, maka segala sesuatu yang dilarang syariat maka ia termasuk dari al-fahsya' (Athiyyah, Al-Muharrar al-Wajiz fi Tafsir alKitab al-Aziz, 2001).

5. Tentang pendapat Muktazilah dalam hal kebebasan manusia bahwa manusia menciptakan perbuatan mereka sendiri, Ibnu Athiyyah menyanggahnya dan menguatkan pendapat Ahlussunnah bahwa Allah yang menciptakan af'al al- 'ibad dan dengan alkasb-lah manusia mendapatkan pahala atau siksa. Misalnya ketika menafsirkan Q.S. alBaqarah ayat 38 dengan tegas Ibnu Athiyyah menyatakan bahwa semua af'al al- 'ibad

${ }^{4}$ Lihat Tafsir Ibnu Athiyyah Q.S. Ali Imran: 31, Q.S al-Baqarah:3, Q. S. al-Baqarah: 22. 
diciptakan Allah yang ditunjukkan dengan lafaz minni pada ayat tersebut (Athiyyah, AlMuharrar al-Wajiz fi Tafsir al-Kitab al-Aziz, 2001). ${ }^{5}$

\section{c. Prinsip Akidah Ketiga: al-Wa'd wa al-Wa'id}

Muktazilah berkeyakinan bahwa Allah wajib memberikan pahala dan siksa kepada manusia, karena jika tidak Allah telah menyalahi janji dan ancamannya. Selain itu mereka juga berpendapat bahwa amal manusia merupakan sebab wajibnya pahala dan siksa tersebut. Jika kita membaca penafsiran Ibnu Athiyyah tentang ayat-ayat yang berkaitan dengan pahala dan siksa, maka akan kita dapati ia menolak pendapat Muktazilah tersebut dan menyatakan bahwa pahala dan siksa tidak wajib bagi Allah, akan tetapi pahala merupakan anugerah dari Allah dan siksa merupakan realisasi keadilan Allah. Sedangkan amal perbuatan manusia menurut Ahlussunnah hanyalah tanda atas pahala atau siksa yang akan diterimanya.

Ketika menafsirkan Q.S. al-A'raf: 44, Ibnu Athiyyah menuturkan bahwa lafadz bima kuntum ta'malun berarti bima kana fi a'malikum min takassub. Allah mengaitkan masuknya manusia ke surga dengan amal perbuatan manusia dalam arti menjadikan amal perbuatan tersebut sebagai tanda masuknya manusia ke surga. Secara literal ayat ini bertentangan dengan hadis Nabi SAW: "seseorang tidak masuk surga karena amal perbuatannya, para sahabat bertanya: "termasuk engkau wahai Rasulullah?” Nabi menjawab: “iya, termasuk saya kecuali Allah melimpahkan karunia dan kasih sayangNya pada saya" (Athiyyah, AlMuharrar al-Wajiz fi Tafsir al-Kitab al-Aziz, 2001). Ayat di atas ditakwil sesuai dengan makna hadis bahwa di antara kasih sayang Allah kepada hambaNya adalah dengan memberinya petunjuk dan taufiq untuk berbuat baik. Hadis tersebut dengan tegas menolak pendapat Muktazilah bahwa secara nalar Allah wajib memberikan balasan surga bagi kaum muslim.

\section{d. Prinsip Akidah Keempat: Pelaku Dosa Besar Kekal di Neraka}

Muktazilah mengimani bahwa pelaku dosa besar yang belum bertaubat sebelum meninggal dunia maka dia kekal di neraka selamanya, namun siksa yang diterima lebih ringan dari pada siksa yang diterima kaum kafir. Ibnu Athiyyah menolak pendapat ini dan menjelaskan dalam tafsirnya dengan pemahaman Ahlussunnah bahwa pelaku dosa besar

\footnotetext{
${ }^{5}$ Begitu juga dengan penafsiran ayat-ayat terkait konsep kasb seperti dalam Q.S. al-Baqarah: 281, Ibnu Athiyyah menjelaskan bahwa kufr dan nifaq diciptakan Allah dan dengan kasb mereka. Lalu, pada Q.S. alNisa': 88 Ibnu Athiyyah menyatakan dengan tegas bahwa ayat ini merupakan nash bahwa pahala dan siksa bergantung pada kasb manusia.
} 
tidak kekal di dalam neraka, namun jika Allah berkehendak maka Allah akan menyiksanya sesuai dengan maksiat yang telah ia perbuat dan jika Allah berkehendak sebaliknya maka Allah akan mengampuninya. Terkait ayat-ayat yang secara zhahir menyatakan kekalnya pelaku maksiat di dalam neraka, Ibnu Athiyyah menakwilkannya dengan dua hal: pertama, menjelaskan bahwa ayat tersebut khusus untuk kaum kafir, maka lafaz khulud di sini bermakna haqiqi, yakni kekal dan abadi. Kedua, menjadikan khulud bermakna majaz metafora, yakni berarti masa yang lama yang diketahui akan berakhir suatu saat nanti bagi orang mukmin yang berbuat maksiat.

Hal ini dapat kita lihat dalam penafsiran Ibnu Athiyyah atas Q.S. al-Baqarah: 81, bahwa lafaz khulud pada ayat tersebut berarti abadi bagi kaum musyrikin dan bermakna rentang waktu yang lama bagi pelaku maksiat -meski diketahui masa itu akan berakhirseperti dikatakan: "raja yang kekal" untuk menyebut raja yang dianggap kekal karena memimpin dalam waktu yang lama, karena pada hakikatnya tidak ada raja yang berkuasa selama-lamanya (Athiyyah, Al-Muharrar al-Wajiz fi Tafsir al-Kitab al-Aziz, 2001).

Pada kesempatan yang lain, ketika menafsirkan Q.S. al-Nisa': 48, Ibnu Athiyyah menjelaskan dengan rinci pendapat-pendapat kelompok Murjiah, Muktazilah, Khawarij dan Ahlussunnah terkait pelaku dosa besar, lalu merajihkan pendapat Ahlussunnah. Ibnu Athiyyah membagi manusia menjadi empat golongan: pertama, orang yang meninggal dalam keadaan kafir, maka ia kekal di dalam neraka menurut ijma' ulama. Kedua, mukmin muhsin tidak melakukan dosa dan meninggal dalam keadaan seperti itu, maka ia dimuliakan di surga menurut ijma' ulama berdasarkan al-Qur'an. Ketiga, orang yang sudah bertaubat dan meninggal maka menurut Ahlussunnah dan jumhur ulama ia masuk surga sebagaimana mukmin muhsin, namun menurut Mutakallimin digantungkan dengan kehendak Allah.

Keempat, orang yang melakukan dosa dan meninggal sebelum bertaubat, ulama berbeda pendapat dalam hal ini. Murjiah mengatakan bahwa ia masuk surga karena keimanannya, dan kesalahan-kesalahannya tidak menghalanginya. Mereka mengkhususkan semua ayat-ayat yang berisi ancaman hanya berlaku untuk orang kafir dan ayat-ayat yang berisi janji berlaku untuk semua orang mukmin secara umum menjadi penjagaan baginya dari siksa neraka. Muktazilah berpendapat bahwa jika ia pelaku dosa besar maka ia kekal di neraka. Sedangkan Khawarij menyatakan baik pelaku dosa besar ataupun dosa kecil, semuanya kekal di neraka, karena mereka berpendapat bahwa semua dosa adalah dosa besar. Mereka mengkhususkan ayat-ayat yang berisi janji bagi orang mukmin muhsin yang tidak melakukan maksiat dan juga bagi mukmin yang bertaubat, sedangkan ayat-ayat yang berisi ancaman berlaku bagi semua yang melakukan maksiat, baik mukmin maupun kafir. Lebih 
lanjut Ibnu Athiyyah menuliskan pendapat Ahlussunnah dan menyatakannya sebagai pendapat yang benar bahwa ayat-ayat al-wa'du wa al-wa'id (janji dan ancaman) sama-sama memiliki redaksi yang umum, sehingga tidak boleh mengkhususkan salah satunya karena saling kontradiksi. Hal ini seperti pada Q.S. al-Lail: 15-16 dan Q.S. al-Jin: 23, maka kita katakan bahwa ayat-ayat janji secara literal bersifat umum namun bermakna khusus bagi mukmin muhsin dan bagi mereka yang bertaubat sebelum meninggal, serta bagi ahli maksiat yang mendapatkan ampunan berdasar ilmu Allah, sedangkan ayat-ayat ancaman memiliki redaksi umum dan bermakna khusus bagi orang-orang kafir dan bagi ahli maksiat yang mendapatkan balasan siksa, maka hal ini sesuai dengan firman Allah "inna Allah la yaghfir an yusyrak bihi wayaghfir ma duna dzalik liman yasya '”, maka jelaslah sudah apa yang menjadi keraguan pada Murjiah dan Muktazilah (Athiyyah, Al-Muharrar al-Wajiz fi Tafsir al-Kitab al-Aziz, 2001).

\section{e. Prinsip Akidah Kelima: al-Amr bi al-Ma'ruf wa an-Nahy 'an al-Munkar}

Pada prinsip akidah Muktazilah yang kelima yaitu al-amr bi al-ma'ruf wa al-nahy 'an al-munkar, tidak ada perbedaan mendasar antara madzhab Muktazilah dan Ahlussunnah terkait wajibnya mengajak kebaikan dan mencegah kemungkaran. Dalam tafsirnya Ibnu Athiyyah menjelaskan ayat-ayat yang memerintahkan amar makruf nahi munkar dengan memandangnya sebagai sebuah kewajiban fardhu kifayah yang cukup dikerjakan oleh sebagian pihak untuk menggugurkan kewajiban tersebut bagi semua. Lebih lanjut Ibnu Athiyyah menetapkan beberapa syarat yang harus diperhatikan dalam melaksanakan amar makruf nahi munkar serta beberapa tingkatan manusia dalam melaksanakan amar makruf nahi munkar (Athiyyah, Al-Muharrar al-Wajiz fi Tafsir al-Kitab al-Aziz, 2001).

\section{Penutup}

Penelitian ini menyimpulkan, berdasarakan hasil analisis kajian pustaka, sebagai ulama bermadzhab Asy'ari, Ibnu Athiyyah menafsirkan ayat-ayat teologis berdasarkan pada pemahaman akidah Ahlussunnah. Begitu juga ketika menafsirkan ayat-ayat teologis yang menjadi dalil bagi prinsip dasar akidah Muktazilah, yaitu: prinsip tauhid, prinsip keadilan Allah, janji dan ancaman (al-wa'd wa al-wa'id), tempat di antara surga dan neraka serta konsep amar makruf nahi munkar. Dalam menjelaskan ayat-ayat teologis tersebut, adakalanya Ibnu Athiyyah Ibnu Athiyyah hanya menyebutkan pendapat yang paling kuat di kalangan Ahlussunnah dan adakalanya menuturkan semua pendapat di kalangan Ahlussunnah dan merajihkan pendapat yang paling kuat. Namun, ada kalanya Ibnu Athiyyah 
menyebutkan pendapat-pendapat dari kelompok lain seperti Muktazilah ataupun Murjiah selain juga pendapat Ahlussunah, kemudian merajihkan pendapat Ahlussunnah dan mengcounter pendapat selainnya. Bahkan, pada beberapa kesempatan Ibnu Athiyyah dengan jelas dan gamblang menolak pendapat Muktazilah dan melemahkannya.

Adapun tuduhan i'tizal yang ditujukan oleh beberapa ulama seperti Ibnu Taimiyyah, Abu Bakr al-Haitami serta Ibnu 'Arafah kepada Ibnu Athiyyah dimungkinkan berawal dari penjelasan Ibnu Athiyyah atas lafadz al-husna dan al-ziyadah pada Q.S. Yunus: 26. Namun, menurut hemat penulis hal ini bukanlah alasan yang kuat untuk menyimpulkan bahwa Ibnu Athiyyah telah menyusupkan paham-paham Muktazilah dalam tafsirnya, karena ayat ini bukanlah teks kunci dalam masalah ru'yatullah dan tidak bisa dijadikan sebagai dalil mustahilnya ru'yah di akhirat. Sedangkan ayat-ayat yang dapat dijadikan dalil atas bolehnya ru'yatullah di akhirat, Ibnu Athiyyah telah memaparkan pendapat-pendapat Ahlussunnah dan Muktazilah disertai dengan sanggahan-sanggahan atas pendapat Muktazilah dan penguatan terhadap pendapat Ahlussunnah.

Karenanya, dapat disimpulkan bahwa tuduhan i'tizal yang dialamatkan kepada Ibnu Athiyyah tidaklah benar. Dalam penafsirannya terhadap ayat-ayat teologi yang berkaitan dengan prinsip akidah Muktazilah, Ibnu Athiyyah berada di barisan ulama Ahlussunnah dilihat dari sikapnya yang merajihkan pendapat Ahlussunnah dan menolak serta menyanggah pendapat Muktazilah. 


\section{DAFTAR PUSTAKA}

Al-‘Akk, K. (1986). Ushul al-Tafsir wa Qawa’iduh. Dar al-Nafais.

Al-Abar, I. (1989). Al-Mu'jam fi Ashhab al-Qadhi al-Shadafi. Dar al-Kitab al-Mishri.

Al-Andalusi, A. H. (1983). Al-Bahr al-Muhith. Dar al-Fikr.

AL-Bukhari, M. bin I. (n.d.). Shahih al-Bukhari. Dar Thauq al-Najat.

Al-Dhabbi, I. U. (1914). Bughyah al-Multamis. Mathba'ah Raukhas.

Al-Dzahabi, M. al-S. H. (2000). Al-Tafsir wa Al-Mufassirun. Maktabah Wahbah.

Al-Dzahabi, M. al-S. H. (2006). Siyar A 'lam al-Nubala'. Dar al-Hadis.

Al-Khathib, I. (n.d.). Al-Ihathah fi Akhbar al-Gharnathah. Dar al-Kutub al-'Ilmiyyah.

Al-Nabbahi, A. bin A. (1984). Tarikh Qudhat Andalus. Dar al-Kitab al-Mishri.

Al-Timisani, A. bin M. al-M. (n.d.). Nafkh al-Thayyib min Ghushni al-Andalus al-Rathib.

Dar Shadir.

Al-Yahshabi, I. bin M. (1982). al-Ghunyah Fahrasat Syuyukh al-Qadhi Iyadh. Dar al-

Gharb al-Islami.

Athiyyah, I. (1983). Fahrasat Ibn Athiyyah. Dar al-Gharb al-Islami.

Athiyyah, I. (2001). Al-Muharrar al-Wajiz fi Tafsir al-Kitab al-Aziz. Dar al-Kutub alIlmiyyah.

Basykuwal, I. (1995). Al-Shilah. Maktabah al-Khanji.

Faudah, M. B. (1987). Tafsir-tafsir al-Qur'an Perkenalan dengan Metodologi Tafsir.

Pustaka.

HAitami, A. bin H. (n.d.). Al-Fatawa al-Haditsiyyah. Mathba'ah al-Taqaddum.

Izutsu, T. (2003). Relasi Tuhan dan Manusia: Pendekatan Semantik terhadap al-Qur'an. Tiara Wacana Karya.

Karim, A. (2013). Rasionalitas Penafsiran Ibnu 'Athi. 12(1), 32.

Khalifah, H. (n.d.). Kasyf al-Zhunun. Muassasah al-Tarikh al-'Arabi.

Rochmad. (2017). Ibnu Athiyyah wa at-Tarjih fi al-Muharrar al-Wajiz. Studia Qur'anika, $1(2)$.

Subhan, M. (2014). Tafsir Ideologis dalam Khazanah Intelektual Islam. Jurnal Mutawatir, $4(1)$.

Taimiyyah, I. (n.d.). Muqaddimah fi Ushul al-Tafsir. Mathba'ah al-Taraqqi.

Zakiyah, E. (2013). Aspek Paham Muktazilah dalam Tafsir al-Kasysyaf tentang Ayat-ayat Teologi (Studi Pemikiran al-Zamakhsyary). In 1 (Tesis). Pascasarjana IAIN Sunan Ampel. 